small and gave rise to no symptoms, so it was left alone. Every case was watched carefully throughout the series for entanglement of the iris; it is possible that a percentage of these 6 cases may have been due to the iris edges having been incompletely returned at the operation. But I do not think this was the case, and I believe they were cases of prolapse. The vision was M.B.E. at 2 metres in 4 cases and at 4.5 and 6 metres respectively in 2 cases.

15. Congestion of the conjunctiva sufficient to demand a note occurred in 10 cases; it did not seriously complicate treatment in any and all did well.

6. There were 4 cases of suppurative iritis. In Case 1 , capsulo-lenticular cataract, iritis commenced gradually on the fourth day and continued to increase in spite of active treatment (atropin, leeches, fomentations, purging, antiseptic irrigations, \&c.); the general health was not good at the time of operation. One is often obliged in India to operate at once in cases which would be better for delay, as the patient cannot afford to wait. Vision = perception of light. Case 2 had been under treatment for the lids (catarrh) for 31 days; the lens was bulky; severe iritis set in the day after operation and was but little influenced by treatment. Vision = perception of light. Case 3 had been treated for eight days for conjunctival congestion before operation; the lens was bulky; suppurative iritis set in on the day after operation and its course was barely modified by active treatment; vision was lost. In Case 4 the conjunctiva was normal, the lens was bulky, and the eye was very inelastic ; several unsuccessful attempts nere made to remove a piece of capsule with iris forceps ; severe iritis set in on the third morning and again active antiphlogistic treatment was adopted. On the next day the anterior chamber was well washed out through the reopened wound with chinosol solution ( 1 in 6000 ) for six minutes. Subsequently the conjunctival sac was freely irrigated thrice daily with the same solution. The chinosol appeared to exercise a very marked effect on the course of the inflammation. Vision $=$ perception of light only.

7. One case of suppurative keratitis occurred; the conjunctiva was normal ; the lens failed to present till after enlargement of the section with scissors; the patient was very stupid. On the third morning a rim of pus was seen round the section which on the seventh day had increased to well-marked suppuration. The patient went out on the twenty-fourth day with some flattening of the cornea. V. = perception of light.

8. There were 3 cases of iritis and 7 cases in which that condition threatened; in every case active antiphlogistic and antiseptic treatment was adopted without delay and all made good recoveries. Vision $=$ M. B.E. at from $1 \cdot 75$ to 3 metres in 9 cases and at 6 metres in 1 case. In all three cases of iritis an operation was required for the treatment of secondary cataract.

9. In only one of the 33 cases of keratitis was the condition at all serious; vision in this case equalled counting fingers at 2 feet; all the rest were slight cases and hardly even modified the course of recovery.

10. In 4 cases the flap was in faulty apposition and in 3 cases the fault was sufficient to require rectification, the flaps being replaced under cocaine; all made good recoveries with vision $=$ M.B.E. at 2 metres.

11. Spasmodic entropion occurred in 3 cases and was met in each care by the removal of all dressings, the eye being left open. In one of these cases the eye was again closed after the lid appeared to have recovered its tone, as the section had not closed; the entropion recurred within 24 hours, causing free lacrymation, \&c. ; on again opening the eye and leaving it open not only did the entropion subside but the section soon healed. Vision in the 3 cases $=$ M. B.E. at $2 \cdot 5,4$, and 6 metres respectively.

12. In one case a pterygium was inflamed; the conjunctiva had been in an unhealthy state before operation and had been treated for the same; the patient rubbed the eye and burst the section and the prolonged bandaging thus rendered necessary irritated the pterygium. Convalescence was delayed and vision $=$ M. B. E. at $1 \cdot 5$ metres.

13 In 16 cases capsulotomy was performed for secondary membranes; of these cases 2 followed iritis, in 9 cases cortical matter had been left behind, in cne blood was effused into the anterior chamber owing to an injury, and in 4 cases the capsule itself was at fault. Tision = M.B.E. at from 1 to 2.5 metres in 10 cases and at from 3 to 6 metres in 6 cases. In the case in which iridotomy was performed the pupil was blocked by a dense membrane the result of iritis; after operation vision was M.B.E, at 2 metres.

Vision on Discharge.

Counted M.B.E. at from 1 to 2 metres ...... 121, or 48.2 per cent.

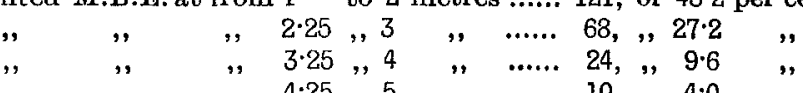

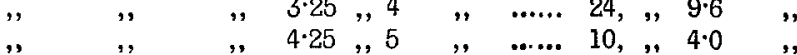

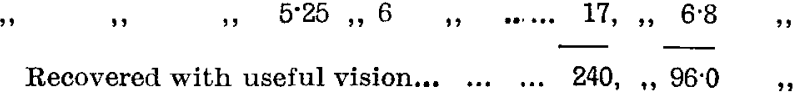

Counted fingers at from half a metre to 1 metre; very poor results, but better than

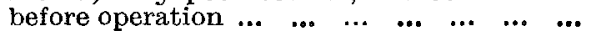
Perception of light only retained $\quad \ldots \quad \ldots \quad \ldots$ $\begin{array}{llllllllll}\text { No vision } & \ldots & \ldots & \ldots & \ldots & \ldots & \ldots & \ldots & \ldots & \ldots\end{array}$ Failures

$5,, 2 \cdot 0$

$4,,, 1.6$

$1,, 0.4$

$5,2 \cdot 0-10$

Near Vision.

Counted the dots of No. I. Jaeger ...... 36, or 14.4 per cent.

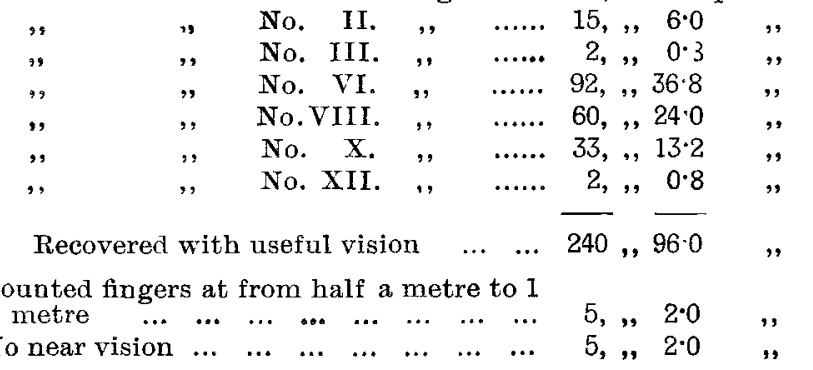

In testing the vision on discharge only spheres were used and even with these a full test could not be given owing to press of work; add to this that many of the patients were very illiterate and jgnorant and that routine necessitated their being tested on discharge (about a week after operation), and it will be conceded by most that the visual results given above were probably in most cases much below the actual standard obtained. Certain it is that one's private cases, which differ from the hospital cases only in superior education and in the fact that one tests them oneself with more leisure than it is possible for the assistant surgeon to give to such large numbers as are dealt with in Indian hospital practice, give much better results. With them, of course, one corrects the astigmatism. I may repeat that a vision of M.B.E. at 6 metres corresponds with a vision of $\frac{6}{10}$ as obtained by the types. This result has been obtained by careful comparative experiments with educated patients after extraction.

To my late assistant Mr. Collins, in subordinate medical charge of the Madras Government Ophthalmic Hospital, I owe my best thanks for the skill with which he always helped me and for the painstaking care which he devoted to the compilation of statistics from my notes.

Madras.

\section{THE RELATION OF MECONIUM TO THE FCETAL APPENDIX.}

By ALEXANDER LOW, M.A., M.B. ABERD.,

LECTURER ON EMBRYOLOGY AND ASSISTANT TO THE PROFESSOR OF ANATOMY, ABERDERN UNIVERSITY

IN his recent Hunterian lectures on the Anatomy and Pathology of the Vermiform Appendix Mr. W. McAdam Eccles in discussing the question of the physiology of the vermiform appendix stated that "the lumen of the appendix is never a receptacle for meconium, so that it would not appear likely that the appendix often has any liquid contents other than what it has itself secreted to absorb." I

In the course of a systematic examination of the foetal abdominal viscera I had frequently noted the presence of meconium in the appendix and on looking up the literature of the subject I have so far been unable to find any reference to this fact; hence I think it well to publish my notes bearing on this point. The accompanying table sets forth the disposition of the meconium in the intestine in the case of 25 consecutive fotuses. In every case the fotus was in good preservation and the abdomen was examined while the 
Table giving a Summary of Observations on the Disposition of the Meconium in the Intestines of 25 HUMAN FogTUSES.

\begin{tabular}{|c|c|c|c|c|c|c|c|c|}
\hline No. & Sex. & $\begin{array}{c}\text { Age of } \\
\text { foetus in } \\
\text { month s. }\end{array}$ & $\begin{array}{c}\text { Length } \\
\text { of toetus } \\
\text { in } \\
\text { milli- } \\
\text { metres. }\end{array}$ & 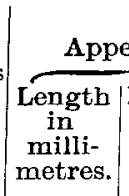 & $\overbrace{\begin{array}{c}\text { Diameter } \\
\text { in } \\
\text { milli- } \\
\text { metres. }\end{array}}^{\text {oendix. }}$ & $\begin{array}{l}\text { Contents of the small } \\
\text { intestine. }\end{array}$ & Contents of the large intestine. & $\begin{array}{l}\text { Contents of the appendix } \\
\text { vermiformis. }\end{array}$ \\
\hline 1 & Female. & $3 \frac{1}{2}$ & 106 & 7 & $0 \cdot 75$ & Eimpty. & Empty. & Empty. \\
\hline 2 & Male. & $4 \frac{1}{2}$ & 200 & 12 & $1 \cdot 0$ & $\begin{array}{l}\text { In the lower portion a } \\
\text { small amount of light- } \\
\text { green meconium. }\end{array}$ & 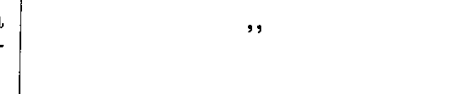 & $"$, \\
\hline 3 & Female. & $4 \frac{1}{2}$ & 205 & 11 & $1 \cdot 5$ & $\begin{array}{l}\text { In the lower two-thirds } \\
\text { darkish-green meconium. }\end{array}$ & $\begin{array}{l}\text { Meconium in the cæeum and } \\
\text { ascending colon. }\end{array}$ & $\begin{array}{l}\text { Darkish-green meconium } \\
\text { in the whole length. }\end{array}$ \\
\hline 4 & Male. & 5 & 230 & 17 & $1 \cdot 0$ & $\begin{array}{l}\text { Light-green meconium in } \\
\text { the lower half. }\end{array}$ & Empty. & Empty. \\
\hline 5 & "' & 5 & 232 & 21 & $1 \cdot 0$ & $\begin{array}{l}\text { Dark-green meconium in } \\
\text { the lower part. }\end{array}$ & $\begin{array}{l}\text { Meconium in the sigmoid } \\
\text { flexure and rectum; the } \\
\text { cæcum was empty. }\end{array}$ & 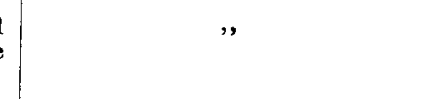 \\
\hline 6 & Fernale. & $5 \frac{1}{2}$ & 236 & 24 & $1 \cdot 5$ & $\begin{array}{l}\text { Dark-green meconium in } \\
\text { the lower half. }\end{array}$ & $\begin{array}{c}\text { Darkish-green meconium in } \\
\text { the whole length. }\end{array}$ & $\begin{array}{l}\text { Dark-green meconium in the } \\
\text { distal half. }\end{array}$ \\
\hline 7 & Male. & $5 \frac{3}{4}$ & 270 & 21 & $2 \cdot 0$ & $\begin{array}{l}\text { Light-green meconium in } \\
\text { the lower part. }\end{array}$ & $\begin{array}{l}\text { Dark-greer meconium in the } \\
\text { cæcum and rectum. }\end{array}$ & $\begin{array}{l}\text { Dark-green meconium in the } \\
\text { proximal half. }\end{array}$ \\
\hline 8 & Fermale. & $5 \frac{3}{4}$ & 270 & 14 & $2 \cdot 0$ & $\begin{array}{l}\text { Light-green meconium in } \\
\text { the lower half. }\end{array}$ & $\begin{array}{l}\text { Dark-green meconium in the } \\
\text { cecum, sigmoid colon, and } \\
\text { rectum. }\end{array}$ & $\begin{array}{l}\text { Dark-green meconium in the } \\
\text { whole length. }\end{array}$ \\
\hline 9 & $"$ & 6 & 282 & 18 & $2 \cdot 25$ & $\begin{array}{c}\text { Traces of greenish me- } \\
\text { conium. }\end{array}$ & $\begin{array}{l}\text { Meconium distended the sig- } \\
\text { moid colon, and rectum; a } \\
\text { small amount in the cæcum. }\end{array}$ & $\begin{array}{l}\text { A trace of meconium along } \\
\text { the whole length. }\end{array}$ \\
\hline 10 & $"$ & 6 & 284 & 21 & $2 \cdot 0$ & $\begin{array}{l}\text { Greenish meconium in the } \\
\text { lower fourth. }\end{array}$ & $\begin{array}{l}\text { Dark meconium distended the } \\
\text { sigmoid colon, and rectum; a } \\
\text { small amount in the cæecum. }\end{array}$ & $\begin{array}{l}\text { Filled with dark meconium } \\
\text { except the distal four milli- } \\
\text { metres. }\end{array}$ \\
\hline 11 & $"$ & 6 & 290 & 20 & $1 \cdot 25$ & $\begin{array}{l}\text { Light-green meconium dis- } \\
\text { tended the lower half. }\end{array}$ & $\begin{array}{l}\text { Dark-green meconium in the } \\
\text { whole length. }\end{array}$ & $\begin{array}{l}\text { Dark-green meconium in the } \\
\text { whole length. }\end{array}$ \\
\hline 12 & Male. & 6 & 292 & 22 & $2 \cdot 0$ & $\begin{array}{l}\text { Traces of brownish } \\
\text { meconium. }\end{array}$ & $\begin{array}{l}\text { Meconium in the sigmoid } \\
\text { colon, and rectum; the cæeum } \\
\text { was empty. }\end{array}$ & Empty. \\
\hline 13 & Female. & 7 & 337 & 32 & $2 \cdot 5$ & $\begin{array}{l}\text { Whilish granular débris in } \\
\text { the lower half. }\end{array}$ & $\begin{array}{l}\text { Greyish granular débris dis- } \\
\text { tended the rectum; a small } \\
\text { amount in the cacum. }\end{array}$ & $\begin{array}{l}\text { Greyish granular débris in } \\
\text { the whole length. }\end{array}$ \\
\hline 14 & ", & $7 \frac{8}{4}$ & 380 & 22 & $2 \cdot 75$ & $\begin{array}{l}\text { Light-green meconium in } \\
\text { the lower half. }\end{array}$ & $\begin{array}{l}\text { Dark-green meconium in the } \\
\text { whole length. }\end{array}$ & $\begin{array}{l}\text { Filled with dark meconium } \\
\text { except the distal four } \\
\text { millimetres. }\end{array}$ \\
\hline 15 & Male. & $7 \frac{3}{4}$ & 380 & 32 & $3 \cdot 0$ & Traces of meconium. & $\begin{array}{l}\text { Dark-green meconium in the } \\
\text { whole length. }\end{array}$ & $\begin{array}{l}\text { Dark-green meconium in the } \\
\text { whole length. }\end{array}$ \\
\hline 16 & $"$, & 8 & 392 & 32 & $2 \cdot 0$ & $\begin{array}{l}\text { Light-green meconium in } \\
\text { the lower part. }\end{array}$ & $\begin{array}{l}\text { Dark-green meconium dis- } \\
\text { tended the whole length. }\end{array}$ & $\begin{array}{l}\text { Dark-green meconium in the } \\
\text { whole length. }\end{array}$ \\
\hline 17 & Female. & 8 & 392 & 18 & $2 \cdot 5$ & $\begin{array}{l}\text { A small amount of meco- } \\
\text { nium in the lower part. }\end{array}$ & $\begin{array}{l}\text { Dark-green meconium in the } \\
\text { whole lengtb; small amount } \\
\text { in the cæcum. }\end{array}$ & $\begin{array}{l}\text { Meconium in the whole } \\
\text { length except distal four } \\
\text { millimetres. }\end{array}$ \\
\hline 18 & , & $8 \frac{1}{2}$ & 418 & 35 & $3 \cdot 5$ & $\begin{array}{l}\text { Light-green meconium in } \\
\text { the lower fourth. }\end{array}$ & $\begin{array}{c}\text { Dark-green meconium in the } \\
\text { whole length. }\end{array}$ & $\begin{array}{l}\text { Distended with dark-green } \\
\text { meconium except the distal } \\
10 \text { millimetres. }\end{array}$ \\
\hline 19 & ", & $8 \frac{1}{2}$ & 420 & 45 & $5 \cdot 0$ & $\begin{array}{l}\text { No solid contents; dis- } \\
\text { tended with gas. }\end{array}$ & $\begin{array}{l}\text { Dark-green meconium dis- } \\
\text { tended the rectum; gas dis- } \\
\text { tended the rest of the intes- } \\
\text { tines. }\end{array}$ & $\begin{array}{l}\text { Distended with gas right } \\
\text { to the apex. }\end{array}$ \\
\hline 20 & $"$, & $8 \frac{1}{2}$ & 432 & 20 & $2 \cdot 0$ & $\begin{array}{l}\text { Traces of darkish meco- } \\
\text { nium in the lower part. }\end{array}$ & $\begin{array}{l}\text { Dark meconium distended the } \\
\text { lower part; a small amount in } \\
\text { the cecum. }\end{array}$ & $\begin{array}{l}\text { Dark meconium in the } \\
\text { distal } 12 \text { millimetres. }\end{array}$ \\
\hline 21 & ", & 9 & 463 & 40 & $3 \cdot 0$ & $\begin{array}{l}\text { Dark-green meconium in } \\
\text { the lower part. }\end{array}$ & $\begin{array}{l}\text { Distended with dark-green } \\
\text { meconium. }\end{array}$ & $\begin{array}{l}\text { Filled with dark-green } \\
\text { meconium in the whole } \\
\text { length. }\end{array}$ \\
\hline 22 & ", & $9 \frac{1}{2}$ & 480 & 42 & $3 \cdot 0$ & $\begin{array}{l}\text { Dark-green meconium in } \\
\text { the jower end. }\end{array}$ & $\begin{array}{l}\text { Dark-green meconium in the } \\
\text { whole length. }\end{array}$ & $\begin{array}{l}\text { Filled with dark-green } \\
\text { meconium to within three } \\
\text { millimetres of the apex. }\end{array}$ \\
\hline 23 &, & $\begin{array}{c}\text { Nearly } \\
\text { full time. }\end{array}$ & 490 & 35 & $3 \cdot 5$ & $\begin{array}{l}\text { A small amount of me- } \\
\text { conium in the lower end. }\end{array}$ & $\begin{array}{l}\text { Distended with dark-green me- } \\
\text { conium in the whole length. }\end{array}$ & $\begin{array}{l}\text { Filled the whole length } \\
\text { with dark-green meconium }\end{array}$ \\
\hline 24 & $"$ & , & 495 & 45 & $3 \cdot 0$ & $\begin{array}{l}\text { Dark-green meconium in } \\
\text { the lower third. }\end{array}$ & $\begin{array}{l}\text { Dark-green meconium in the } \\
\text { whole length. }\end{array}$ & $\begin{array}{c}\text { Dark-green m iconium in the } \\
\text { whole length. }\end{array}$ \\
\hline 25 & Male. & Full time. & 560 & 60 & $4 \cdot 0$ & $\begin{array}{l}\text { Rather distended with dark- } \\
\text { green meconium in the } \\
\text { lower third. }\end{array}$ & $\begin{array}{l}\text { Only traces of dark-green me- } \\
\text { conium in the whole length. }\end{array}$ & $\begin{array}{l}\text { Distended with dark-green } \\
\text { meconium in the whole } \\
\text { length. }\end{array}$ \\
\hline
\end{tabular}


fœtus was still quite fresh. In the table the notes have been rearranged according to the approximate age of the fœetus.

Case 13 is of interest as in this foetus there was obliteration of the bile-ducts and the meconium was represented by greyish granular débris. Case 19 was a premature child who lived for 24 hours. The abdomen was examined 12 hours after death and it was found that meconium was present in the rectum only and that the rest of the alimentary canal, including the appendix, was distended with an inodourless gas. This gas could be squeezed from the appendix into the crecum and on removing the pressure the gas again re-distended the appendix. Case 25 was the foetus from a case in which labour was protracted and instrumental. Here the large intestine was contracted and contained only slight traces of meconium, while the appendix was quite distended with dark-green meconium.

Although the series of fotuses examined is small, still from the tabulated facts it appears that the disposition of the meconium with regard to the different portions of the fœtal intestinal canal is as follows :-

1. Small intestine.-Meconium begins to distend the lower half about the middle of the fourth month and continues to do so to a variable extent till the end of fotal life.

2. Large intestine.-Meconium begins to distend the rectum about the beginning of the fifth month, thereafter tending to accumulate in the cæcum and then gradually distending the whole of the large intestine, so that after the seventh month dark-green meconium distends the large intestine in its whole length.

3. Appendix vermiformis.-Meconium was noted to be present in the appendix as early as the middle of the fourth month and thereafter in nearly every case it was present in the appendix till the end of foetal life. The amount of meconium in the appendix varies; it seems to depend somewhat on the condition of the cæcum-if the cæcum is distended then the appendix is always distended, but there may be meconium in the appendix while the cæcum is practically empty.

$$
\text { Aberdeen. }
$$

\section{A CASE OF ACUTE YELLOW ATROPHY OF THE LIVER.}

BY W. FERRIS, M.B , B.S. LOND., M.R.C.S. ENG., L.R.C.P. LOND., D.P.H.,

FOURTH ASSISTANT MEDICAL OFFICER AND PATHOLOGIST TO THE MIDDLESEX COUNTY ASYLUM; LATE ASSISTANT MEDICAL OFFICER TO THE GREENWICH INFIRMARY;

AND

W. H. OLAYTON-GREENE, B.A., M.B., B.C. CantaB., F.R.C.S. ENG.,

SURGICAL REgISTRAR TO ST. MARY'S HOSPITAL; IAATE ASSTSTANT DEMONSTRATOR OF PATHOLOGY AT CAMBRIDGE UNIVERSTTY.

ACUTE yellow atrophy of the liver is so very seldom met with that there is little chance for the accurate study of its causation and minute pathology or for the clinical recognition of the significance of its group of symptoms. I [W. F.] venture, therefore, to publish the notes and comments on the following case of this affection which came under my care in 1900, trusting that it may be of interest to the readers of THE LANCET.

It was not until the year 1836 that this disease was first rec Jgnised and described by Bright, although prior to that year a few cases having a similar grouping of symptoms were reported by prominent physicians of their period. Bright described it as a diffuse inflammation of the liver, affecting the glandular substance more than the connective tissue, causing diminution in the size of the whole organ, and being characterised by jaundice associated with hæmorrhages and severe nervous symptoms. Busk and Handfield-Jones were the next English physicians to study its microscopical pathology and they pointed out that the liver cells themselves underwent a definite degeneration. Since that time various accounts of the disease have been published by physicians of many nationalities, but no definite conclusions can be arrived at as to its origin and causation. I have reported the case as presented in the hospital and $\mathrm{Mr}$ Clayton Greene supplies the microscopical pathology and remarks at the end.

An unmarried woman, aged 23 years, was admitted to the Greenwich Infirmary on May 28th, 1900, suffering from jaundice. Her mother said that she had always been in good health, with the exception of a sore throat occasionally, till April 12th or thereabouts in 1900, when she caught cold and was laid up for a week with a bad throat; this, however, got better and the patient went to her work regularly till about May 5th, when she was seized with jaundice, general malaise, and pain in the abdomen and had to stay at home and receive medical attendance. Sometimes she was obliged to stay in bed owing to intense sickness, flatulence, and severe cramp in the legs, but on other occasions she felt better and was up and about the house. As the jaundice did not disappear her medical attendant thought that it was advisable to send her to the infirmary. According to the personal history of the patient which was obtained from her mother she had had measles when a little child but had never suffered from rheumatism or chorea. She was always regular in menstruation. She was very reticent as regards her affaires $d u$ cour, but she admitted to her mother that she used to "walk out" with a man who just prior to her illness had left to take part in the Boer war. She had no other trouble or worry that her mother knew of. As regards the family history the patient's mother was well in health and her father, who drank freely, died from phthisis at the age of 38 years. Two brothers died in infancy and a sister had died seven years before with uræmic coma. One brother is alive and well.

On admission to the infirmary the patient was seen to be well nourished, well developed, and inclined to obesity. The skin was coloured a deep yellow from head to foot. The conjunctivæ were a bright yellow. The pupils were dilated, the reflexes being normal. The respirations were normal and the pulse was 96, regular in force and frequency and moderately compressible. To any question put to her her answer was the same-viz., her surname. The tongue was dry and coated with a pale brown fur, except at the tip and edges. The abdomen moved well on respiration and was not distended. The spleen or the edge of the liver could not be felt. Deep palpation below the right costal border caused the patient to wince as if in pain, but she did not complain of anything. The liver dulness could only be obtained for one inch cn a level with the sixth rib in the vertical nipple line. The lungs appeared to be normal. A soft puffing systolic murmur could be heard over the pulmonary area of the heart; elsewhere the sounds were normal and no murmur was audible. At the time of admission she was menstruating.

The progress of the case was as follows. On the night of the 28th she slept well, having taken a pint of milk and soda-water. She did not vomit and she passed urine involuntarily. One and a half ounces of compound mixture of senna were administered. The bowels were not opened. On the 29th she was very strange in her manner during the day and was constantly trying to get out of bed. She took food well, consisting of milk, beef-tea, and soda-water. There was an evacuation after an enema. The temperature at $6 \mathrm{P} . \mathrm{M}$. was $98.8^{\circ} \mathrm{F}$. The urine was drawn off with a catheter and was tested; the result showed an acid reaction, the colour being dark brown; it was clear and its specific gravity was 1016. It contained no albumin and no sugar. On evaporation and examination under the microscope leucin crystals were seen. Gmelin's test for bile pigment gave a positive result. A diagnosis of acute yellow atrophy was made. At night the patient was very restless till 11 P.M. She retched once but did not vomit, and she slept heavily the rest of the night. The bowels were not opened, but she passed urine involuntarily. On the 30 th the temperature at $10 \mathrm{~A}$. M. was $98 \cdot 8^{\circ}$. The abdomen still appeared to be tender in the right hypo. chondrium on deep palpation. The patient did not speak all day ; she was very restless, she groaned occasionally, and tried to get out of bed several times, but she took nourishment well. The bowels were opened very slightly; the motions were dark brown in colour and were formed. The pulse was 112, soft and compressible. The temperature at 6 P.M. was $99^{\circ}$. During the night she was very restless, sleeping only for short intervals, constantly moaning, and throwing the clothes off. She still, however, took nourish. ment well and there was no vomiting. She passed urine involuntarily. Between 4 and $5 \mathrm{~A} . \mathrm{M}$. the patient had two convulsive seizures, with twitchings of both arms and face. and she remained rigid after 5 A.M. The rigidity passed off about $9 \mathrm{~A} . \mathrm{M}$. on the $31 \mathrm{st}$; the temperature at $10 \mathrm{~A} . \mathrm{M}$. on this day was $101^{\circ}$. The patient was unconscious all day. 